\title{
Study on Vertical Position Reading Noise from Beam Position Monitor in Pohang Light Source Storage Ring Vacuum Chamber
}

\author{
Youngdo Joo, Changbum Kim, IImoon Hwang, and Chongdo Park* \\ Pohang Accelerator Lab., Pohang 790-784 \\ (Received October 26, 2010, Revised January 10, 2011, Accepted January 11, 2011)
}

\begin{abstract}
A sudden step change is observed in the vertical position readings from beam position monitors (BPMs) mounted at the several sector vacuum chambers of Pohang Light Source. To study the source of this sudden step change, we measured the RF transmission scattering matrix $\left(\mathrm{S}_{21}\right)$ through the pickup electrodes of BPMs mounted at the both ends of the sector vacuum chamber. The measured $S_{21}$ graph of the sector vacuum chambers suffering sudden step change has a peak in the BPM operation frequency bandwidth. Otherwise that of the other sector vacuum chambers doesn't have a peak. It is shown by the numerical simulation that the peak found in the BPM operation frequency bandwidth corresponds to the longitudinal harmonic of transverse electric resonance mode.
\end{abstract}

Keywords : Beam position monitor, Transverse electric field mode, Vacuum chamber, Pohang light source

\section{Introduction}

The beam position monitor (BPM) [1,2] mounted in the storage ring of Pohang Light Source (PLS) consists of four pickup electrodes which are coupled to the electron beam in capacitive way. When the electron beam goes through the storage ring beam chamber, the electric potential is induced at the electrodes due to the image charge on the surface of beam chamber. Then the horizontal and vertical position of electron beam is measured by the potential difference between electrodes as shown in Fig. 1. The measured beam position is used for beam orbit correction feed-back loop. However, it has been reported by many physicists in several light sources that the sudden step change occurs in the vertical position reading from BPMs in the vacuum chambers of storage ring [3-5].

The storage ring of PLS is not free from this sud-

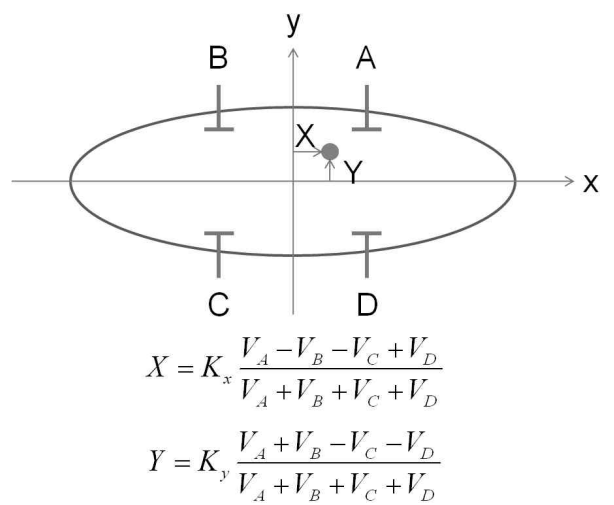

Figure 1. Conceptual drawing of BPM. The offset distances in the direction of $\mathrm{x}$ and $\mathrm{y}$ are calculated by the simple analytic equation.

* [E-mail]cdp@postech.ac.kr 
den step change either. To avoid this BPM signal noise, the operation frequency of these noise suffering BPMs has been changed from normal value of 500 $\mathrm{MHz}$ to $375 \mathrm{MHz}$. The beam filling pattern is also modified to have a blank bucket after every three beam bunches. However, this temporary solution increases the charge of each electron beam bunches and causes more cost to maintain the additional BPM systems for the different frequencies. Furthermore, it is planning to install only two BPMs in a sector vacuum chamber of storage ring of PLS-II, the PLS upgrade project. Therefore, it is significantly requested to study the origin of BPM signal noise in the storage ring of PLS.

In this study, we measured the RF transmission scattering matrix $\left(\mathrm{S}_{21}\right)$ through the pickup electrodes of BPMs mounted at both the ends of the sector vacuum chamber. Furthermore, finite-difference time-domain (FDTD) simulation of the sector vacuum chambers was carried out to determine the field distribution of resonance modes.

\section{BPM vertical position reading in the PLS storage ring}

The time varying profiles of beam current, gap of insertion devices (IDs), horizontal and vertical position readings of BPM $6,7,8$, and 9 in the cell 8 on 21, Mar. 2009 is shown in Fig. 2. The position of BPMs is shown in Fig. 3. There are three sudden step changes in the vertical position readings of BPM. The step 1 may be caused by the change of ID gap, and the step 2 and 4 are caused by the beam injection to storage ring. However, the origin of the step 3 is not clear.

Many causes, for instances, ground motion of storage ring, irregular change of current from magnet power supply and electrical misbehaving of BPM boards are considered. However, these causes

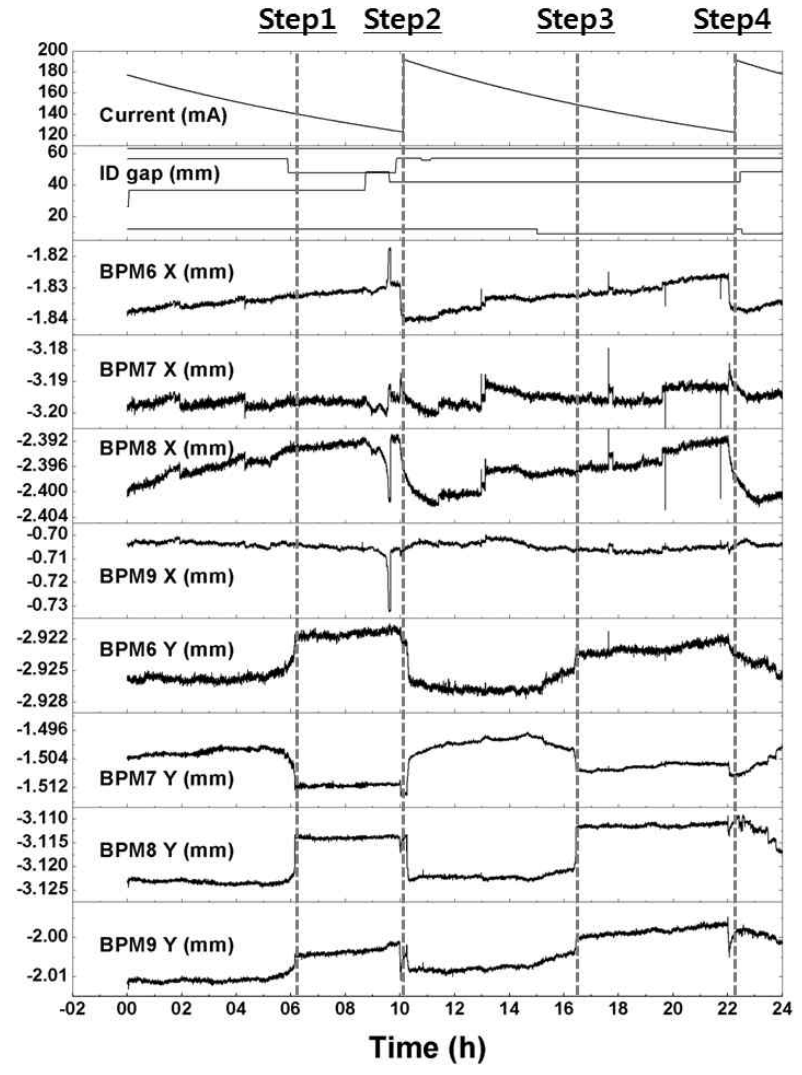

Figure 2. The one day time variation of beam current, gap of insertion devices (IDs), horizontal and vertical BPM position readings of cell 8 on 21, Mar. 2009.

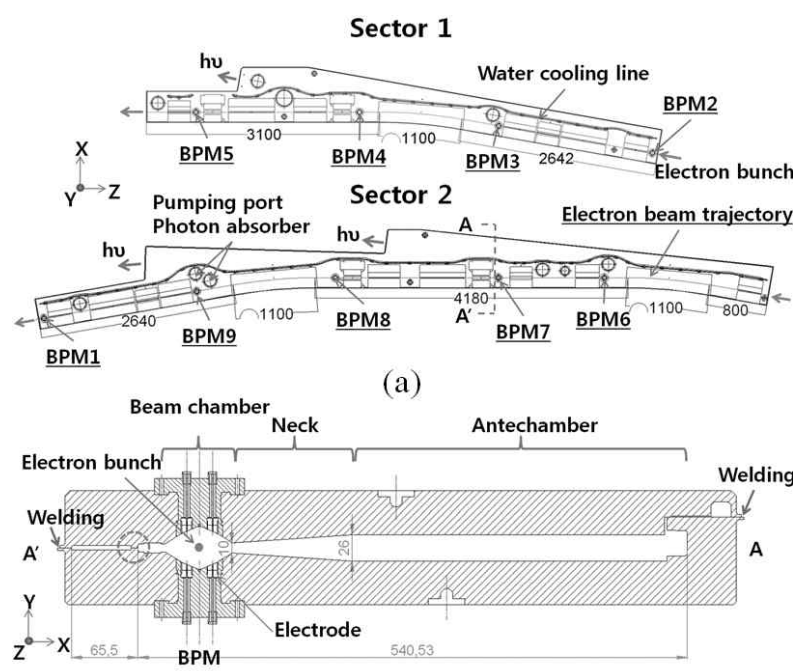

(b)

Figure 3. The top-view of the vacuum chamber of a cell of PLS storage ring with positions of BPMs. 
cannot explain that the direction of vertical offset is not uniform in the different BPMs and the horizontal position readings are relatively quiet. At last, it is suspected that the sudden step change in vertical BPM position reading is correlated with the resonance modes inside vacuum chamber, because To verify that the origin of BPM noise is resonance mode in the vacuum chamber, the resonance modes near the 0.5 $\mathrm{MHz}$ frequency band centered on the $500 \mathrm{MHz}$ where the BPMs are sensitive should be investigated.

The large horizontal width of sector vacuum chambers of PLS is required to extract and block synchrotron and to install vacuum components as shown in Fig. 3 [6]. Therefore, the beam chamber is connected to the antechamber through the neck with small height and as shown in Fig. 4. The role of neck area is to provide good conductance for vacuum pumping and for transmission of the photons into the beam port. It was well known that the beam-induced transverse magnetic (TM) mode propagates to antechamber through this neck area with small height thus the fields are confined in the beam chamber with small volume $[7,8]$. Therefore the cutoff frequency of TM mode is much higher than $500 \mathrm{MHz}$.

However, the cutoff frequency of TE mode can be lower than $500 \mathrm{MHz}$ because of the extended width of vacuum chamber for the neck area and antechamber. Furthermore, the neck area with a small height introduces a large capacitive loading that lowers the cut-off frequency for TE modes of the chamber in comparison to a rectangular waveguide having the

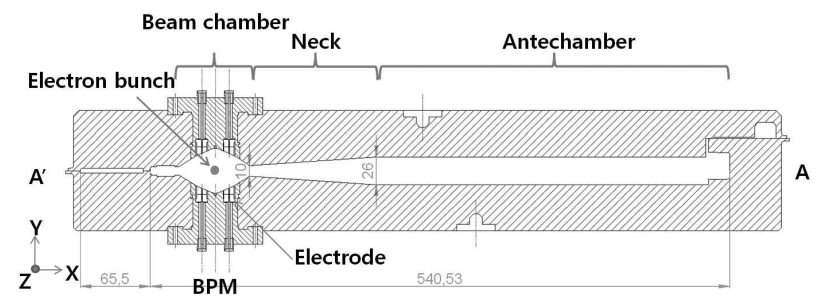

Figure 4. Cross section of normal vacuum chamber of PLS storage ring $\mathrm{A}-\mathrm{A}$ ' line shown in Fig. 3. The length of antechamber varies. same width. Therefore, it is possible for the harmonic of $\mathrm{TE}$ mode to be excited at the operation frequency of BPM.

\section{Experimental measurement of PLS vacuum chamber}

To experimentally invest the resonance TE modes excited in PLS vacuum chamber, the $S_{21}$ between BPM ports, without beam, is measured using vector network analyzer (VNA) as shown in Fig. 5. The signal from the port 1 of VNA is feed to amplifier to get the enough incident power to the beam chamber. Here, to protect amplifier and VNA from reflection power, a circulator and a load is used. It is measured by the power meter that the incident power to BPM port is about 10 watt. Because the incident power to the BPM port is electrically coupled to inside of the beam chamber and it is vertically connected to the beam chamber, the TE mode is excited inside of beam chamber. When the TE mode is arrived at the other BPM port, the pick-up signal is coupled to the port 2 of VNA. Then, we can get the S21 graph in the frequency domain using VNA. The BPM pickup electrodes of BPM 6 and BPM 1 mounted at opposite ends of the sector 2 vacuum chamber are used in the measurement.

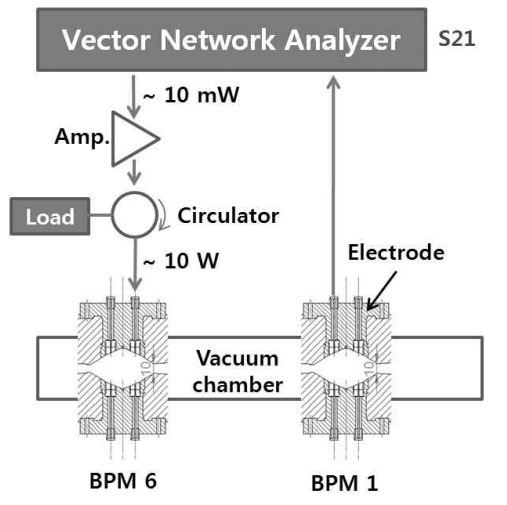

Figure 5. Experimental setup for the measurement of $\mathrm{RF}$ power transmission through BPM ports. 
Here, we selected two cells from the total twelve cells of PLS storage ring. One is the cell \#12 where the noise from TE mode is frequently observed and the other is cell \#9 where no TE mode noise is observed. The measured S21 graph is shown in Fig. 6.

The $S_{21}$ graph of the cell 12 seems to be translated from that of the cell 9. The peak for cell 9 is find out of the blue line but that of cell 12 is found inside the beamwidth of the BPM operation frequency. This explains why the BPM signals of cell 9 are not corrupted by the TE mode but those of cell 12 are corrupted by TE mode. The reason why frequencies of eigenmodes are different between each cells is under study.

\section{Numerical simulation of resonance modes in PLS vacuum chamber}

Both ends of a sector vacuum chamber and the beam port are connected to the bellows with small radius, and thus, the sector vacuum chamber can be modeled as a cavity with electric boundaries. Therefore, in the FDTD simulation, CST Microwave Studio (MWS), an eigenmode solver is used to study the field distribution of the resonance mode excited inside a sec-

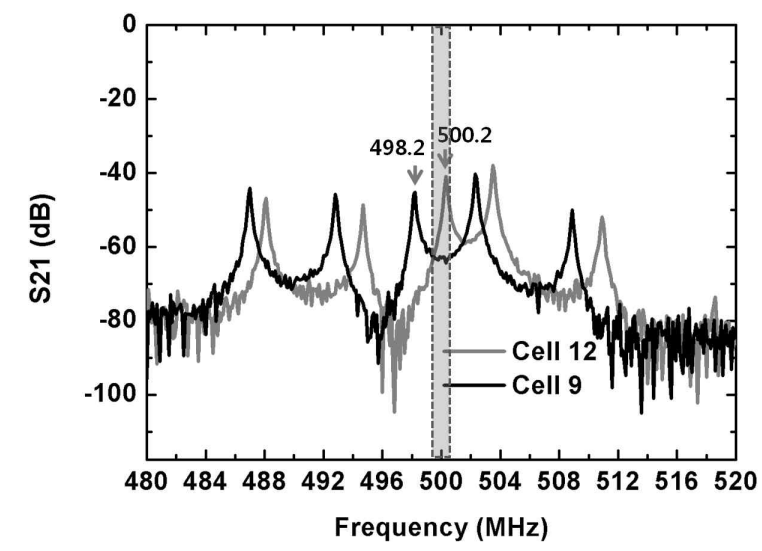

Figure 6. RF transmission parameter (S21) through the BPM ports of BPM6 and BPM1. The colored area means the bandwidth of bandpass filter on the BPM signal board. tor vacuum chamber. The simulation model of sector 2 vacuum chamber of PLS storage ring is shown in Fig. 7. Only the vacuum is shown. The vertical photon absorber is also included. We find eigenmodes near the BPM operation frequency and trace by increasing of mesh numbers as shown in Fig. 8. The eigenmode frequencies are converged as the mesh number increases and matched with the peak frequencies in the measured $\mathrm{S} 21$ graph with about $1 \mathrm{MHz}$ differences. These differences are caused by the neglect of strip NEG structure, the assumption of perfect conductor and simplified simulation model. Therefore the experimental measurement is well matched with numerical calculation.

The electric field distribution of the resonance mode near $500 \mathrm{MHz}$ is shown in Fig. 9. The electric

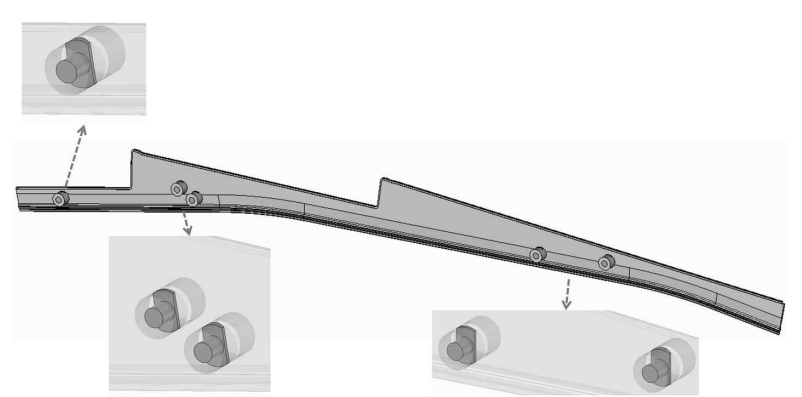

Figure 7. Simulation model of sector 2. Photon absorbers are inserted.

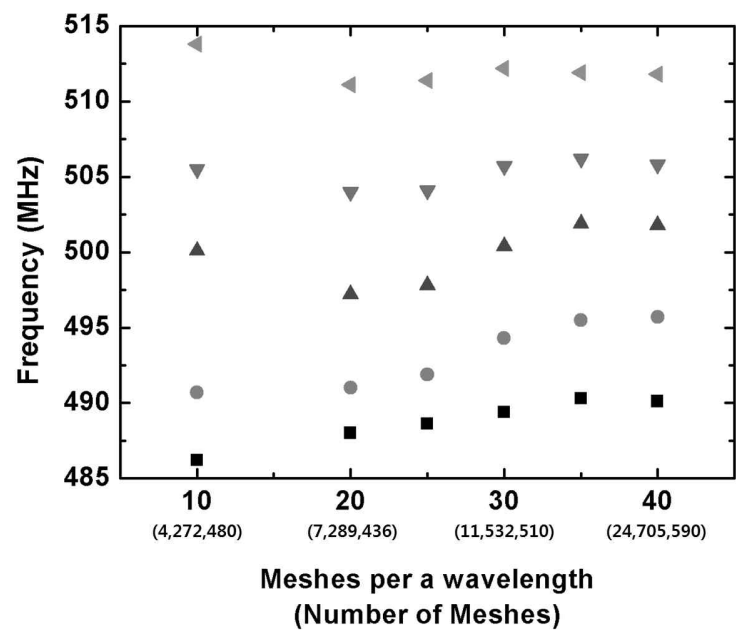

Figure 8. Simulation result of sector 2. The mesh optimization is shown. 


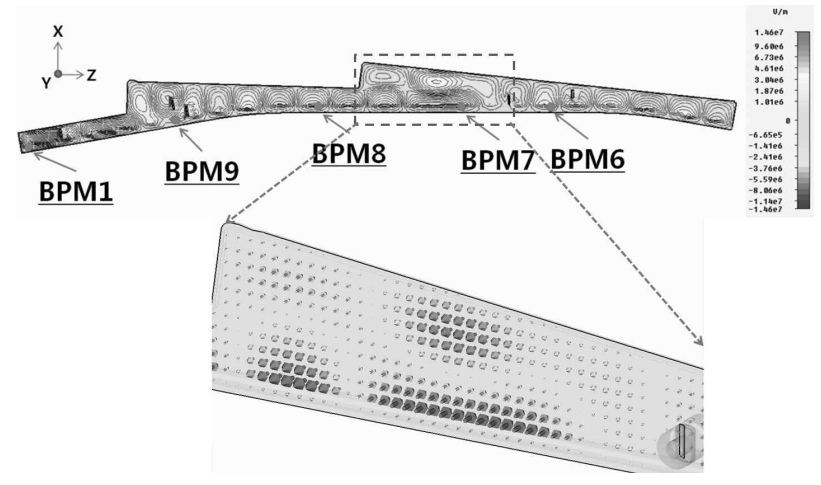

Figure 9. The electric field contour plot of the Eigenmode near the BPM operation frequency of $500 \mathrm{MHz}$. The vertically oriented electric field near the BPM is shown.

field is oriented in the vertical direction, which means that the resonance mode excited in the sector vacuum chamber is one of the longitudinal harmonics of the TE resonance mode.

Thus, the vertical position reading has a sudden step change when the TE resonance mode is excited and amplified to a certain level during operation of the storage ring. The physical process of excitation and amplification of the TE resonance mode of the sector vacuum chamber will be investigated in a future study.

\section{Conclusion}

In this study, we numerically and experimentally analyze the resonance mode excited in a sector vacuum chamber of the PLS to find the source of spurious BPM signal noise. It is verified that the vertical offset noise of a BPM in the PLS storage ring is caused by the vertically oriented electric field of the longitudinal harmonic of the TE resonance mode. On the basis of this study, we are now under designing a sector vacuum chamber of the PLS-II free from the TE resonance mode and will publish the results of this work soon.

\section{References}

[1] J. Y. Huang, J. Korean Phys. Soc. 48, 768.

[2] E. Kahana, Proc. The 3rd accelerator beam instrumentation workshop, AIP conference proceedings 252, 235-240 (1992).

[3] X. Sun and G. Decker, APS internal note LS-299, (2003). http://www.aps.anl.gov/Science/Publications/ lsnotes/ls299.pdf.

[4] Y. Kang, G. Decker, and J. Song, Proc. Particle Accel. Conf. 1999, 3092.

[5] H. Hseuh, ASAC Review of NSLS-II, 1, 1-21 (2009).

[6] C. K. Kim, K. H. Kil, W. C. Choi, and S. Y. Park, J. Korean Vac. Soc. 1, 24-27 (1992).

[7] R. Kustom, J. Bridges, W. Choi, J. Cook, G. Mavrogemes, and G. Nicholls, Proc. 1989 IEEE PAC, pp. 1755-1759 (1989).

[8] R. Wehrle, J. Moenich, S. Kim, and R. Nielsen, Proceeding of IEEE PAC, pp. 1669-1671 (1987). 


\section{포항광가속기 저장링 진공용기의 빔위치측정기의 위치 측정 오류에 대한 연구}

주영도 · 김창범 · 황일문 · 박종도*

포항공과대학교 포항가속기연구소, 포항 790-784

(2010년 10월 26일 받음, 2011년 1월 10일 수정, 2011년 1월 11일 확정)

포항광가속기의 섹터 진공용기에 부착된 빔위치측정기의 수직방향 위치 읽음 값이 갑자기 변하는 오류가 관찰되었다. 이 오류 의 원인을 알기 위해서 섹터 진공용기의 양 끝단에 있는 빔위치측정기의 전극을 통한 고주파전달 산란계수를 측정하였다. 급 한 변화를 보이는 섹터 진공용기에서는 측정한 산란계수의 첨단 값이 빔위치측정기의 작동 주파수 내에 존재함을 확인하였고, 전산시늉을 통해 빔위치측정기의 작동 주파수내 첨단 주파수가 가로 전장 모드의 공진모드와 일치함을 확인하였다.

주제어 : 빔위치측정기, 가로전장모드, 진공용기, 포항광가속기

*[전자우편] cdp@postech.ac.kr 